13. Cameron E. Normalising testing - normalising AIDS. Forum Lecture, Ronald Louw Memorial Campaign: 'Get tested, get treated'. University of KwaZuluNatal, Durban, 4 May 2006

14. Bayer R, Fairchild A. Changing the paradigm for HIV testing - the end of exceptionalism. N Engl J Med 2006;355:647-649.

15. Frieden T, Das-Douglas M, Kellerman S, Henning K. Applying public health principles to the HIV epidemic. N Engl J Med 2005;353(22):2397-2402.

16. Macklin R. Scaling up HIV testing: Ethical issues. Health and Human Rights 2005;8(2):27-30

17. Bayer R, Edington C. HIV testing, human rights, and global AIDS policy: exceptionalism and its discontents. J Health Polit Pol Law 2009;34(3):301-323.

18. WHO. Treat 3 Million by 2005 Initiative. Geneva: World Health Organization, 2003.

19. UNAIDS. Guidance on Provider-initiated HIV Testing and Counselling in Health Facilities. Geneva: World Health Organization, 2007.

20. Leon NH, Colvin CJ, Lewin S, Mathews C, Jennings K. Provider-initiated testing and counselling for HIV - from debate to implementation. S Afr Med J 2010;100(4):220-221.

21. Department of Health. HIV \& AIDS and STI Strategic Plan for South Africa 2007-2011. Pretoria: Department of Health, 2007.

22. Department of Health. Clinical Guidelines for the Management of HIV \& AIDS in Adults and Adolescents 2010. http://www.doh.gov.za/docs/factsheets/ guidelines/adult_art.pdf (accessed 11 April 2010).

23. South African National AIDS Council. Change in Policy Guidelines. April 2010. http://www.sanac.org.za/press-room/in-the-news/change-in-policy-guidelines (accessed 11 April 2010).

24. Matovu JK, Makumbi FE. Expanding access to voluntary HIV counselling and testing in sub-Saharan Africa: alternative approaches for improving uptake, 2001-2007. Trop Med Int Health 2007;12(11):1315-1322.

25. Ganguli I, Bassett IV, Dong KL, Walensky RP. Home testing for HIV infection in resource-limited settings. Current HIV/AIDS Rep 2009;6(4):217-223.

26. Smetherham J. Unemployed Cape Town men paid to take HIV tests. Cape Times 21 April 2009
27. Merson MH, Feldman EA, Bayer R, Stryker J. Rapid self testing for HIV infection. Lancet 1997;349(9048):352-353

28. Hicks JM. Home testing: to do or not to do? Clin Chem 1993;39(1):7-8

29. Schuklenk U, Kleinsmidt A. Rethinking mandatory HIV testing during pregnancy in areas with high HIV prevalence rates: ethical and policy issues. Am J Public Health 2007;97(7):1179-1183.

30. Fleshman M. AIDS prevention in the ranks - UN targets peacekeepers, combatants in war against the disease. Africa Recovery 2001;15(1-2):16-18.

31. Shisana O, Rehle T, Simbayi L, et al. South African National HIV Prevalence, Incidence, Behaviour and Communication Survey, 2008 - A Turning Tide Among Teenagers? Cape Town: HSRC Press, 2009.

32. President of the Republic of South Africa. Commencement of certain sections of the National Health Act, 2003 (Act No. 61 of 2003). Proclamation notice No. R.20, 2010. Pretoria: Government Gazette No. 33187, 14 May 2010.

33. Minister of Health. National Health Act (61/2003) regulations: Withdrawal of blood from a living person for testing. Government Notice No. R.401. Pretoria: Government Gazette No. 33187, 14 May 2010.

34. Department of Health. National Policy on Testing for HIV. Pretoria: Department of Health, August 2000.

35. La Greca AM, Bearman KJ. Commentary: If 'An apple a day keeps the doctor away', Why is adherence so darn hard? J Pediatr Psychol 2001;26(5):279-282.

36. The South African Pharmacy Council. Good Pharmacy Practice in South Africa. 3rd ed. Pretoria: The South African Pharmacy Council, 2008.

37. Palles M, Jürgens R. Home testing for HIV: Potential benefits and pitfalls. Canadian HIV/AIDS Policy \& Law Newsletter 1996;3(1):19-20.

38. Cameron E. Stigma, human rights, testing and treatment - Time for Action. SA HIV Clinicians' Society Ruben Sher Memorial Lecture 2009. Johannesburg: 26 November 2009.

39. Walensky RP, Paltiel AD. Rapid HIV testing at home: Does it solve a problem or create one? Ann Intern Med 2006;145:459-462.

\title{
MEDICINE AND THE LAW \\ Standards for the reporting of sex/sexual activity of minors in a research context
}

\author{
Arvin Bhana, Sharlene Swartz, Adlai Davids
}

While there are no specific protocols for dealing with reports of sexual abuse of children, the Criminal Law (Sexual Offences and Related Matters) Amendment Act of 2007 (Act No. 32 of 2007) clearly stipulates that, in the event of a report of sexual abuse by a child or any other person of the abuse of a child, the relevant person has the

The authors are researchers in the Human and Social Development and HIV/AIDS, STIs and TB Research Programmes of the Human Sciences Research Council (HSRC), and are members of the HSRC Ethics Committee. legal (statutory) obligation to report such abuse to the police; and that it replaces previous legislation where reporting could be done to a social worker or the police. According to the Child Advocate, a disclosure by a child (specific child, specific offender) is sufficient to require such reporting.

Given this statutory requirement, research with children that focuses on children's sexuality and reproductive health is likely to encounter instances of abuse of children. According to the Act, a child is any person below the age of 18 ; but with reference to Sections 15 and 16 of the Act, it refers also or specifically refers to any person below the age of 16 . In this report, all ages up to 17 are referenced as children. To adequately address the response of this requirement within a research context, where the involvement of law enforcement can easily jeopardise the research, the following standard operating practice is recommended:

1. Any child of 17 years or younger who reports abuse (as defined in the Act), or on whose behalf abuse is reported by a peer, care 


\section{Table I.}

Examples of the protocol in practice

Action by researcher

A 14-year-old tells of having sex with her 17-year-old boyfriend

A 12-year-old reports 'having sex' with 19-year-old neighbour

Childline $\rightarrow$ Police

An 11-year-old tells of a previously reported incident of 'bad touching' by an adult aunt that went to court

Childline $\rightarrow$ Police

No action. Ask if the child wants to talk

to someone

A 15-year-old relates rape by father

A 13-year-old boy relates anecdote of sex with 15-year-old girlfriend (consensual underage sex)

Childline $\rightarrow$ Police

Not $>2$-years rule applies, so no action. If age is uncertain, report to Childline

A 13-year-old says he or she is 'having sex' but does not disclose with whom

No action

A 17-year-old brags that he has 'forced' many girls into having sex with him

No action, but recommendation of counselling would be appropriate

A 17-year-old pupil speaks of having being made pregnant by a teacher whom she does not identify

Would she want to speak to a professional counsellor?

A 18-year-old pupil points out a female teacher with whom he says he is 'sleeping'

Would she want to speak to a professional counsellor?

giver/guardian or family member or other relevant person, will trigger an immediate termination of further interviews with the respondent and members of the household. (Such termination is subject to the researcher complying with any reporting duties required by law in terms of paragraph 3 below.)

2. If there is a clear statement that the parties to the abuse involve an adult (anyone 18 or older) or anyone who is more than 2 years older (Section 56(2) (b)) than the child, the interviewer shall report the matter to Childline South Africa at toll-free number 0800055 555. Childline will then contact a registered social worker in the area who will investigate and inform the South African Police Service (SAPS) accordingly. The interviewer will record details of the child's name, physical address and the school attended. As proof of meeting the statutory reporting obligation, the interviewer must obtain a Childline reference number as proof of reporting. Section 56(2) (b) only applies where both the parties are children.

3. If there is a clear statement that the individuals involved in the abuse (i.e. non-consensual sex) are peers (not more than 2 years older than the victim), the matter is referred to the nearest office of the Department of Social Development. Section 56(2) (b) does not apply to non-consensual sex. In the case of consensual underage sex, where the parties involved are no more than 2 years apart in age, no reporting action will be taken (see Table I for possible actions).

4. Any secondary reporting of abuse (i.e. where children indicate that they reported the abuse to a teacher or another adult, and no action was taken) will be brought to the attention of Childline, who will deal with the matter. Again, the interviewer will obtain a Childline reference number as proof of reporting.

An important basis for making decisions about reporting instances of sexual abuse is that the researcher needs to be clear that there was an age difference of more than 2 years between the child and the other party. It must be reiterated that this rule in section 56 (2) (b) of the Act only applies where both parties are children and the sex is consensual. If there is uncertainty or lack of clarity, the researcher must consult with the project manager or director, but continue with the research. In addition, while Childline may assist in reporting abuse, the onus remains on the researcher to ensure that the police are informed; this requires diligent follow-up on reporting by the researcher. 